\title{
Physicochemical and Antioxidative Characteristics of Potato Protein Isolate Hydrolysate
}

\author{
Chiung-Yueh Chang ${ }^{1}$, Jinn-Der Jin ${ }^{2}$, Hsiao-Li Chang ${ }^{2}$, Ko-Chieh Huang ${ }^{1}$, Yi-Fen Chiang ${ }^{1}$ \\ and Shih-Min Hsia $1,3,4,5, * \mathbb{D}$ \\ 1 School of Nutrition and Health Sciences, College of Nutrition, Taipei Medical University, Taipei 110, Taiwan; \\ d507104001@tmu.edu.tw (C.-Y.C.); a910241@gmail.com (K.-C.H.); yvonne840828@gmail.com (Y.-F.C.) \\ 2 GeneFerm Biotechnology Co., Ltd., Tainan 741, Taiwan; jin168@geneferm.com (J.-D.J.); \\ gracechang@geneferm.com (H.-L.C.) \\ 3 Graduate Institute of Metabolism and Obesity Sciences, College of Nutrition, Taipei Medical University, \\ Taipei 110, Taiwan \\ 4 School of Food and Safety, Taipei Medical University, Taipei 110, Taiwan \\ 5 Nutrition Research Center, Taipei Medical University Hospital, Taipei 110, Taiwan \\ * Correspondence: bryanhsia@tmu.edu.tw; Tel.: +886-2-2736-1661
}

Received: 3 September 2020; Accepted: 25 September 2020; Published: 28 September 2020

\begin{abstract}
This study investigated the physicochemical characteristics of potato protein isolate hydrolysate (PPIH) and its antioxidant activity. Potato protein isolate (PPI) was hydrolyzed into PPIH by the proteases bromelain, Neutrase, and Flavourzyme. Compared with PPI, the resulting PPIH had a lower molecular weight (MW, from 103.5 to $422.7 \mathrm{Da})$ and smaller particle size $(<50 \mathrm{~nm})$, as well as a higher solubility rate $(>70 \%)$ under acidic conditions ( $\mathrm{pH} 3-6)$. PPIH presented good solubility $(73 \%)$ across the tested $\mathrm{pH}$ range of $3-6$. As the $\mathrm{pH}$ was increased, the zeta potential of PPIH decreased from -7.4 to -21.6 . Using the 2,2'-azino-bis-3-ethylbenzthiazoline-6-sulfonic acid (ABTS) radical-scavenging assay, we determined that the half-maximal effective concentration $\left(\mathrm{EC}_{50}\right)$ values of ascorbic acid, PPIH, and PPI were $0.01,0.89$, and $>2.33 \mathrm{mg} / \mathrm{mL}$, respectively. Furthermore, PPIH $(50 \mu \mathrm{g} / \mathrm{mL})$ protected $\mathrm{C} 2 \mathrm{C} 12$ cells from $\mathrm{H}_{2} \mathrm{O}_{2}$ oxidation significantly better than PPI $(10.5 \%$ higher viability rate; $p<0.01$ ). These findings demonstrated the possible use of PPIH as an antioxidant in medical applications.
\end{abstract}

Keywords: potato protein isolate; hydrolysate; physicochemical characteristics; solubility; antioxidant

\section{Introduction}

Potato is the world's fourth most important food crop, and it contains abundant carbohydrates and proteins [1]. The potato starch industry releases large quantities of potato fruit juice (as a byproduct), which is rich in protein [2]. Potato protein has an excellent amino-acid score and is considered a nutritious dietary protein source [3]. Potato protein isolate (PPI) can be isolated from potato fruit juice using a combination of acidic precipitation and thermal coagulation [4]. The PPI is divided into three fractions: patatin (up to $40 \%$ ), protease inhibitors (50\%), and other high-molecular-weight (MW) proteins $(10 \%)$. Patatin is a glycoprotein with an MW of $39-43 \mathrm{kDa}$ (existing as native $80 \mathrm{kDa}$ dimers) with different isoelectric point $(p I)$ values ranging from $\mathrm{pH} 4.45-5.17$. Patatin is a good emulsifier with foaming and gel-forming capacity and good stability [5]. Patatin contains several free-radical-scavenging amino acids, including tryptophan, phenylalanine, methionine, cysteine, histidine, and tyrosine, presenting antioxidant and angiotensin-converting enzyme, (ACE)-inhibitory activity [6,7]. Patatin has also been used to facilitate cheese ripening [8,9]. The protease inhibitors, with MWs ranging from 4.3 to $20.6 \mathrm{kDa}$, exhibit $p I$ values of $\mathrm{pH}$ 5.1-9.0. The other high-MW proteins 
are mainly composed of oxidative enzymes including lipoxygenase, polyphenol oxidase, and several enzymes associated with starch synthesis [10].

Enzymatic hydrolysis is an attractive approach for utilizing proteins to achieve increased value $[11,12]$. Specifically, proteolysis is capable of breaking proteins into peptides with desired size, charge, and surface hydrophobic properties and further improving their antioxidative properties [13]. Enzymatic hydrolysis is capable of converting PPI into PPI hydrolysate (PPIH) with different molecular sizes, charges, and physicochemical characteristics. PPIH has attracted much attention in recent years due to its antioxidant activities. For example, PPIH showed antioxidative activity and reduced glutathione (GSH) produced by $\mathrm{Fe}(\mathrm{II}) / \mathrm{H}_{2} \mathrm{O}_{2}$-induced oxidation [10]. Kudo et al. [14] indicated that potato protein hydrolysate inhibited linoleic-acid oxidation and ferric-thiocyanate oxidation. Moreover, enzymatic hydrolysis has the favorable potential to remove antinutritive factors such as protease inhibitors [15]. Therefore, much attention has been paid to exploring the influences of enzymatic hydrolysis on the physicochemical and antioxidative properties of PPIH.

Endoproteases and exoproteases including bromelain, Neutrase, and Flavourzyme have been used to hydrolyze proteins to produce protein isolate hydrolysates showing antioxidant activities [16]. Among these proteases, bromelain (EC 3.4.22.32) is a cysteine endoprotease derived from pineapple stems, and it has also been demonstrated to be a safe and effective food supplement [17]. Neutrase (EC 3.4.24.28) is a neutral, zinc metalloendoprotease from Bacillus amyloliquefaciens with an optimum activity at $\mathrm{pH} 5.5-7.5$ and $30-55^{\circ} \mathrm{C}$. This enzyme randomly hydrolyses internal peptide bonds to break down proteins to peptides. Furthermore, Flavourzyme is sold as a peptidase preparation from Aspergillus oryzae. This enzyme preparation is diversely and widely used for protein hydrolysis in research and industrial applications. In total, eight enzymes, namely, three endopeptidases (alkaline protease 1, EC 3.4.21.63; neutral protease 2, EC 3.4.24.39; neutral protease 1, EC 3.4.24), two aminopeptidases (leucine aminopeptidase 2, EC 3.4.11; leucine aminopeptidase A, EC 3.4.11), two dipeptidyl peptidases (dipeptidyl peptidase 4, EC 3.4.14.5; dipeptidyl peptidase 5, EC 3.4.14), and one amylase ( $\alpha$-amylase A type 3, EC 3.2.1.1), were identified [18]. These protein isolate hydrolysates are versatile and play a major role in a wide range of applications in the food industry.

Researchers have demonstrated the potent antioxidative activity of PPIH. They have also demonstrated its applicability as a food additive in vegetarian and elderly-friendly dishes and amino-acid supplements; however, the physicochemical characteristics of PPIH have not been reported. To investigate the physicochemical characteristics of PPIH and its antioxidant activity, PPI was hydrolyzed by bromelain, Neutrase, and Flavourzyme. The solubility, MW distribution, particle size, microstructure, and zeta potential of the resulting PPIH were determined. The 2,2'-azino-bis-3-ethylbenzthiazoline-6-sulfonic acid (ABTS) radical-scavenging assay of PPIH and its antioxidant effect on muscle $\mathrm{C} 2 \mathrm{C} 12$ cells were also evaluated. Therefore, the aim of this study was to investigate the physicochemical characteristics of PPIH and its antioxidative activity on C2C12 murine myoblast cells.

\section{Results and Discussion}

\subsection{Solubility of PPI and PPIH Samples under Acidic Conditions}

Protein solubility can also be affected by $\mathrm{pH}$, and the $\mathrm{pIs}$ for most PPIs are between 4.5 and 6.5; therefore, proteins were precipitated in this $\mathrm{pH}$ region [2]. Figure 1 indicates the solubility of PPI and PPIH over a $\mathrm{pH}$ range of 3-6. PPI presented poor solubility across this $\mathrm{pH}$ range. A similar protein solubility profile of PPI was reported by Akbari et al. [11], with a solubility of $\sim 30 \%$ at $\mathrm{pH} 3-5$. The authors reported that PPI was prepared by heat coagulation and acid precipitation, and these processes cause PPI to have low solubility. Moreover, PPI generally aggregated at a pH level close to its isoelectric $\mathrm{pH}$. By contrast, $\mathrm{PPIH}$ presented good solubility across the entire $\mathrm{pH}$ range. Compared to that of PPI, we noticed that the solubility of PPIH at its isoelectric $\mathrm{pH}$ was significantly increased. The solubility of PPIH was significantly higher than that of PPI in a pH range of 3-6. This result 
indicated that PPIH was more easily dissolved in acid solution than PPI. Hou et al. [19] indicated that the hydrolysis of proteins increased the functional properties of proteins such as solubility and emulsifying properties, mainly in heat-denatured proteins. Pęksa and Miedzianka [20] suggested that peptide bond cleavage and a decrease in the MW by enzymatic hydrolysis increased the number of ionizable carboxyl and amino groups $\left(\mathrm{COO}^{-}\right.$and $\mathrm{NH}_{3}{ }^{+}$, respectively). Therefore, the protein solubility improved due to the electrostatic repulsion between peptides and, thus, protein-water interactions. Therefore, the increased solubility of PPIH could be due to smaller peptides being produced by protease. As is known, a higher protein solubility is particularly important in acidic protein drinks in which sedimentation and precipitation are undesirable. Due to the increased PPIH solubility, especially at low $\mathrm{pH}$, the application of these compounds will increase in acidic drinks and diets.

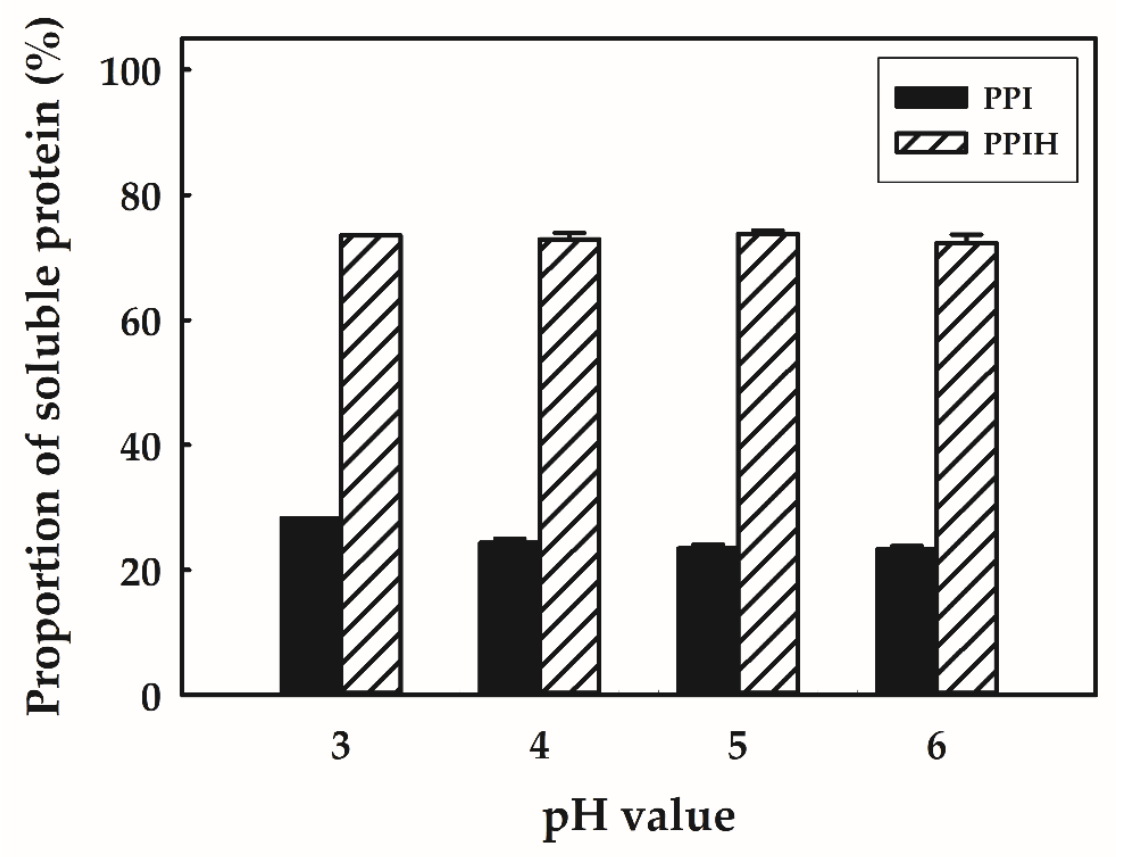

Figure 1. Effect of $\mathrm{pH}$ on the solubility of potato protein isolate (PPI) and PPI hydrolysate (PPIH). Each value is represented as the mean \pm SD.

\subsection{Zeta Potential of PPI and PPIH Samples under Acidic Conditions}

Peptides are amphoteric molecules, containing both acidic and basic amino acids. The ionizable groups in proteins are the C-terminal carboxyl group, N-terminal amino group, and ionizable groups on side chains. Both $\alpha$-carboxyl and $\alpha$-amino groups are ionized, and the molecule becomes dipolar. Therefore, the zeta potentials of PPI and PPIH in a pH range of 3-6 were also investigated. As shown in Figure 2, as the $\mathrm{pH}$ was increased, the zeta potential of PPI decreased from -1.9 to -17.8 . According to our results, the net negative charge of the PPI samples increased with increasing buffer $\mathrm{pH}$. As mentioned previously, the pIs for PPI are between 4.5 and 6.5. The $p I$ is the $\mathrm{pH}$ at which a particular molecule carries no net electrical charge. The net charge on the molecule is affected both by its own $p I$ and by the $\mathrm{pH}$ of the buffer. At a $\mathrm{pH}$ above their $\mathrm{pI}$, proteins carry a net negative charge; below their $p I$, they carry a net positive charge. This fact suggested that the zeta potential of PPI $(1.9 \pm 0.3 \mathrm{mV})$ at $\mathrm{pH} 3.3$ was similar to the $\mathrm{pI}$. Similar trends of zeta potential were also observed in the PPIH results. As the $\mathrm{pH}$ was increased, the zeta potential of PPIH decreased from -7.4 to -21.6 . These results suggested that the zeta potentials of PPI and PPIH under acidic conditions ranged from 0 to $-22 \mathrm{mV}$. Cheng et al. [21] reported that PPIH at $\mathrm{pH} 7.0$ had a net negative charge, and the zeta potential of PPIH at pH 3-7 ranged from -0.2 to $-6.2 \mathrm{mV}$. Schmidt et al. [22] also reported that the zeta potential of PPI at pH 7.0 was $-5.7 \mathrm{mV}$. Chuacharoen and Sabliov [23] reported that the zeta potential has long been accepted as a good measure for assessing the stability of a nanoparticle system. The statistical 
analysis of the data revealed that there was a significant difference in zeta potential, whereas all values represented a good degree of stability, as it was reported that, with a zeta potential lower than $-25 \mathrm{mV}$ or higher than $+25 \mathrm{mV}$, colloids could be obtained because of a greater electrostatic repulsion between nanoparticles [24].

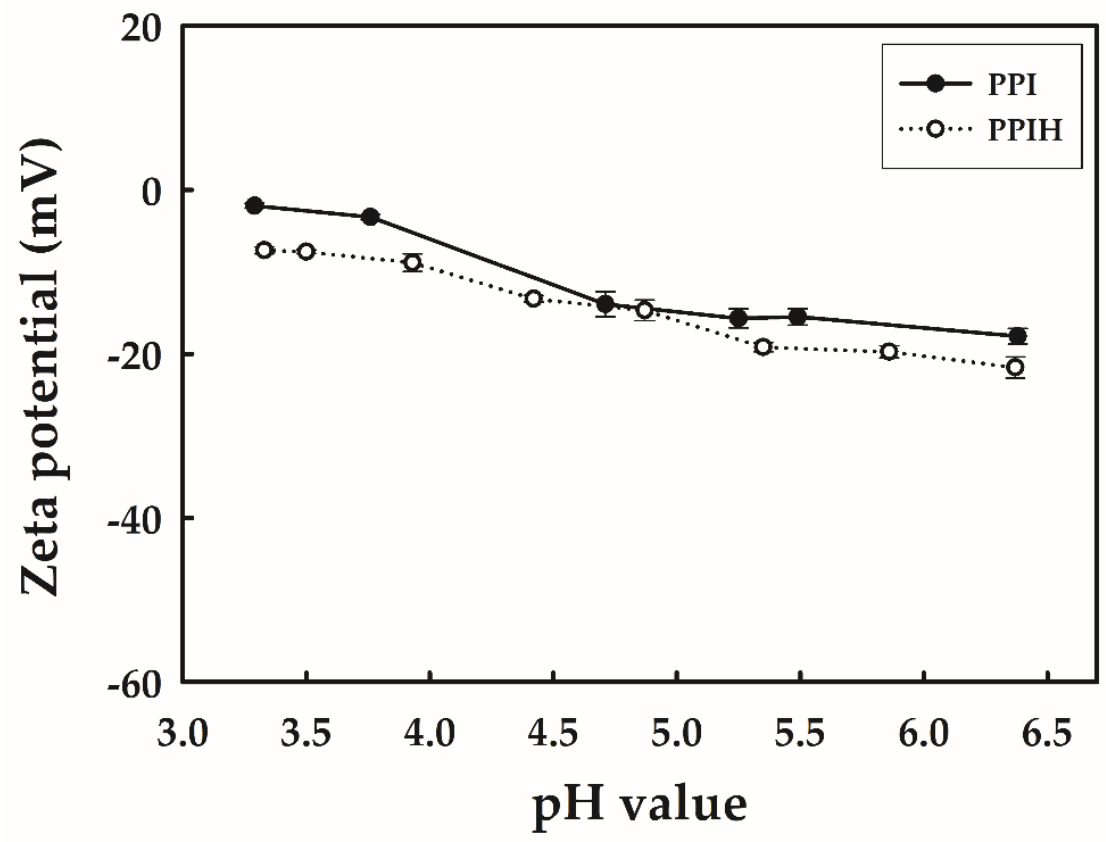

Figure 2. Effect of $\mathrm{pH}$ on the zeta potential of PPI and PPIH. Each value is represented as the mean \pm SD.

\subsection{Particle Size and TEM Analysis of PPI and PPIH Samples}

Klompong et al. [25] reported that enzymatic hydrolysis is used in the modification of protein structure, resulting in small peptides with improved physicochemical properties. Therefore, particle size and TEM analysis of PPI and PPIH were conducted. The particle size distribution of PPI was approximately as follows: $0-50 \mathrm{~nm}$ particles, $0 \%$ yield; $100-400 \mathrm{~nm}$ particles, $13 \% \pm 4 \%$ yield; 7000-10,000 nm particles, $87 \pm 4 \%$ yield. However, the particle size distribution of PPIH was approximately as follows: 0-50 nm particles, $100 \%$ yield; $100-400 \mathrm{~nm}$ particles, $0 \%$ yield; 7000-10,000 nm particles, $0 \%$ yield. We noticed that most of the particle sizes of the PPI and PPIH were approximately 7000-10,000 nm and 0-10 nm, respectively. This observation indicated that the particle size of PPIH was smaller than that of PPI. Midelfort and Wittrup [26] reported that proteins can form highly specific and structured complexes via self-assembly in a number of ways. These protein particles were formed as a result of aggregation and could span many orders of magnitude, from oligomers spanning tens of nanometers to visible aggregates spanning several hundred micrometers [27]. Ryan et al. [28] reported that TEM could be used to evaluate the aggregate shape of proteins. Therefore, the particle sizes of PPI and PPIH were also analyzed by TEM (Figure 3). As shown in Figure 3A, high-MW aggregates of PPI were observed. The length of these PPI particles was 117-355 nm. Furthermore, we found high-MW aggregates of PPIH, as shown in Figure 3B. The lengths of these PPIH particles were 3-50 nm. The microstructure of the PPI and PPIH displayed the appearance of aggregated nanoparticle structures. We noticed that compared with the PPI, the PPIH significantly decreased in typical dimensions. Therefore, the PPIH particles were smaller than the PPI particles. These TEM results suggested that PPI and PPIH were aggregated to form larger aggregates. 
(A)PPI

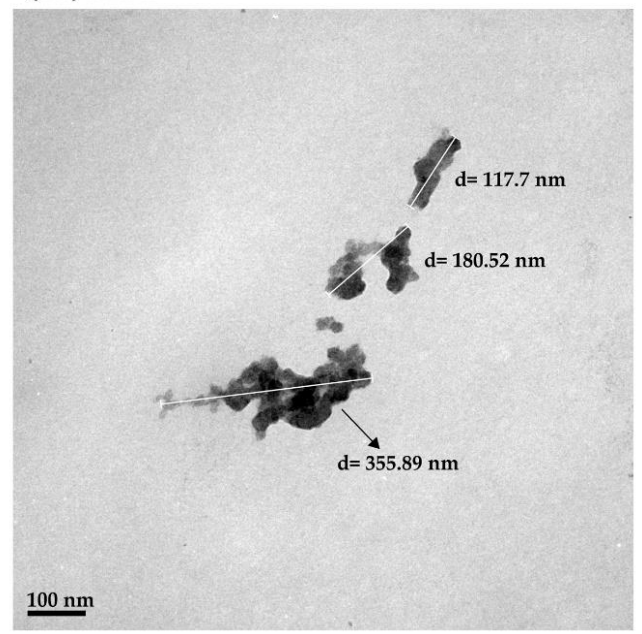

\section{(B) PPIH}

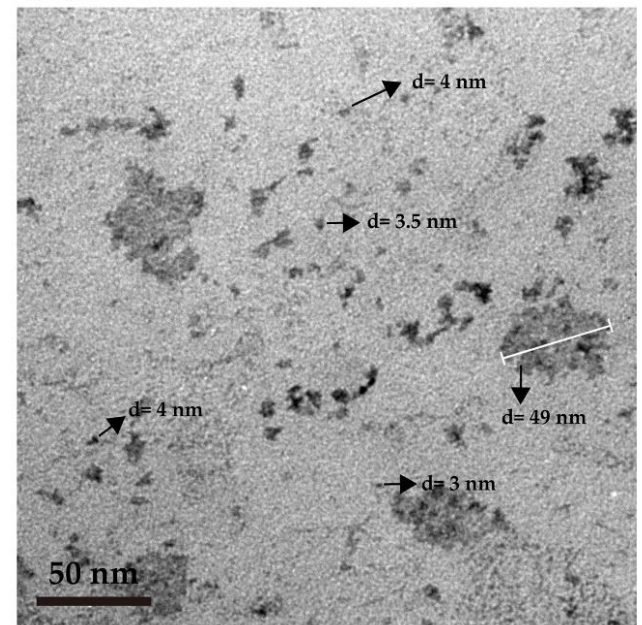

Figure 3. TEM analysis of PPI (A) and PPIH (B).

\subsection{SDS-PAGE and Mass Spectrometry Analysis of PPI and PPIH}

The PPI can roughly be divided into patatin, protease inhibitors, and oxidative enzymes, which account for approximately $40 \%, 50 \%$, and $10 \%$ of the total proteins, respectively [29]. As shown in Figure $4 \mathrm{~A}$, the PPI and PPIH samples were analyzed by SDS-PAGE, which separated patatin $(\sim 33 \mathrm{kDa})$, protease inhibitors $(16-20 \mathrm{kDa})$, and oxidative enzymes $(75-80 \mathrm{kDa})$ in the PPI sample. However, SDS-PAGE analysis indicated that no protein bands were observed in the PPIH sample. These results suggested the enzymatic hydrolysis of PPI to PPIH through peptide bond cleavage. Li et al. [30] suggested that protein hydrolysates have lower MW ranges than native proteins. Therefore, the PPIH sample was further analyzed by mass spectrometry (Figure 4B). The results indicated that the PPI was digested to hydrolysate with an MW of $<500 \mathrm{Da}$, and most PPIH samples had mass-to-charge $(\mathrm{m} / \mathrm{z})$ ratios of 103.5-422.7. This observation indicated that smaller peptides were produced by enzymatic hydrolysis of PPI into PPIH.

(A)

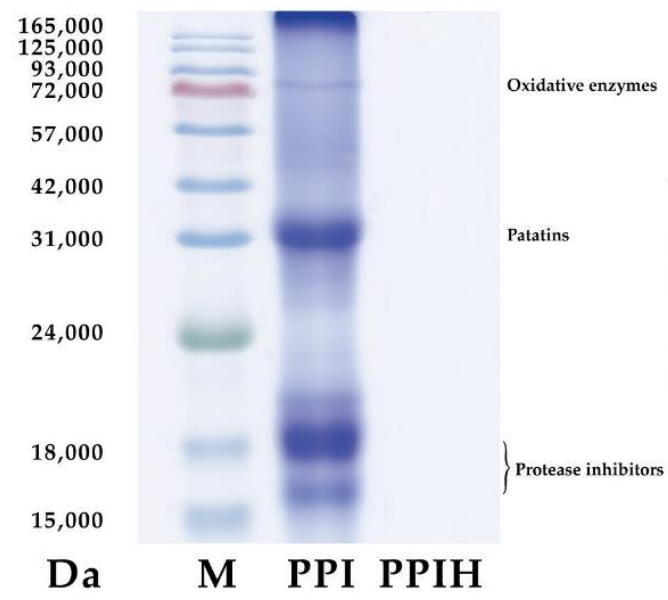

(B)PPIH

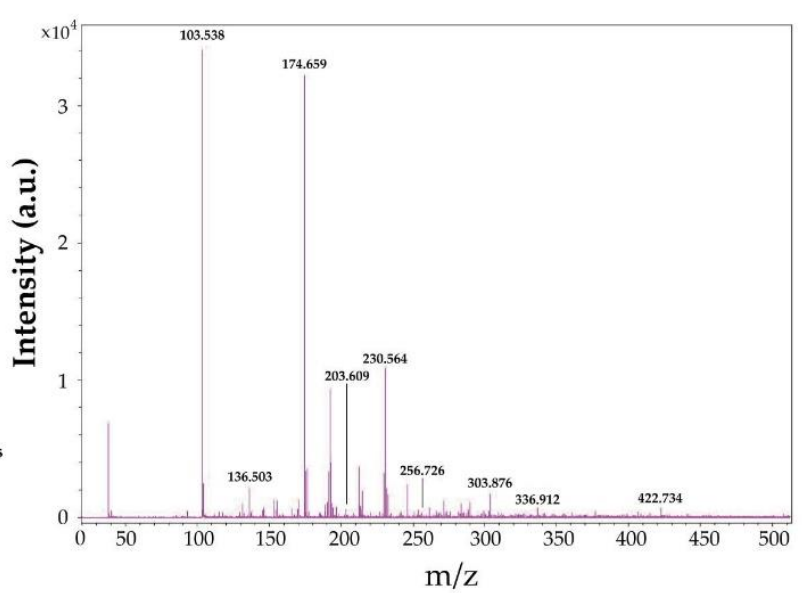

Figure 4. SDS-PAGE (A) and mass spectrometry analysis (B) of PPI and PPIH. M: MW standard.

\subsection{Antioxidant Effects of PPIH on Muscle C2C12 Cells}

Protein hydrolysates have been reported to have numerous health benefits such as antioxidative effects [31]. Li et al. [30] reported that hydrolysates with lower MW ranges had better antioxidant activity than native proteins. Therefore, the ABTS antioxidant activity of PPIH was evaluated. When $0.5,0.75$, 
1.0, and $1.25 \mathrm{mg} / \mathrm{mL}$ PPIH were added, the ABTS radical-scavenging effect (\%) values were 33.9\% $\pm 1.4 \%$, $44.4 \% \pm 1.1 \%, 53.2 \% \pm 1.0 \%$, and $64.0 \% \pm 0.8 \%$, respectively. The PPIH sample presented antioxidant activity at various concentrations. The half-maximal effective concentration $\left(\mathrm{EC}_{50}\right)$ values of ascorbic acid, PPIH, and PPI were 0.01, 0.89, and $>2.33 \mathrm{mg} / \mathrm{mL}$, respectively. The $\mathrm{EC}_{50}$ values of ascorbic acid, PPIH, and PPI were in the following order: ascorbic acid $<$ PPIH $<$ PPI. PPIH did not present the strong antioxidant properties of ascorbic acid and may, therefore, be suitable for medical purposes as an antioxidant. There is at present no evidence to support its use as a dietary supplement. Cheng et al. [32] reported that PPIH $(5 \mathrm{mg} / \mathrm{mL})$ exhibited strong ABTS radical-scavenging activity and antioxidant activity. Various peptides with specific amino-acid sequences are released after hydrolysis, and these protein hydrolysates possess significant antioxidant activity [33]. Kudo et al. [14] reported that the three peptides Phe-Gly-Glu-Arg, Phe-Gly-Glu-Arg-Arg, and Phe-Asp-Arg-Arg isolated from PPIH showed antioxidative activities. The antioxidative activities of these three peptides were compared to those of butylated hydroxyanisole. As a result, Phe-Gly-Glu-Arg, Phe-Gly-Glu-Arg-Arg, and Phe-Asp-Arg-Arg inhibited linoleic-acid oxidation by $55.3 \%, 61.7 \%$, and $58.5 \%$ using the $\beta$-carotene decolorization assay system, respectively.

Furthermore, Hood et al. [34] reported that skeletal muscle has a unique ability to increase the use of oxygen during contraction. During intense activity, the high rate of $\mathrm{O}_{2}$ consumption in skeletal muscles can cause electron leakage from the electron transfer chain and incomplete oxygen reduction, leading to the generation of reactive oxygen species (ROS). Cellular and tissue injury is associated with ROS in many kinds of disorders [35]. Kerasioti et al. [36] reported that whey protein $(0.5 \mathrm{mg} / \mathrm{mL})$ showed protective activity against oxidative stress since a decrease in ROS levels in muscle cells (C2C12 cells) was observed. The whey protein was effective in scavenging $\mathrm{H}_{2} \mathrm{O}_{2}$ and protecting $\mathrm{C} 2 \mathrm{C} 12$ cells from oxidative stress-induced damage. Thus, the protective effects of PPIH on $\mathrm{H}_{2} \mathrm{O}_{2}$-induced oxidative injury in skeletal muscle cells (C2C12 murine myoblast cells) were further evaluated. As shown in Figure 5, the results indicated that $\mathrm{H}_{2} \mathrm{O}_{2}(0.2 \mathrm{mM})$ or PPI $(50 \mu \mathrm{g} / \mathrm{mL})$ alone significantly reduced the cell viability of skeletal muscle cells compared with the control (without $\mathrm{H}_{2} \mathrm{O}_{2}$ ). Compared with PPI $(50 \mu \mathrm{g} / \mathrm{mL})$, PPIH $(50 \mu \mathrm{g} / \mathrm{mL})$ significantly increased the protective effect against $\mathrm{H}_{2} \mathrm{O}_{2}$-induced oxidative injury in skeletal muscle cells by $10.5 \%(p<0.01)$.

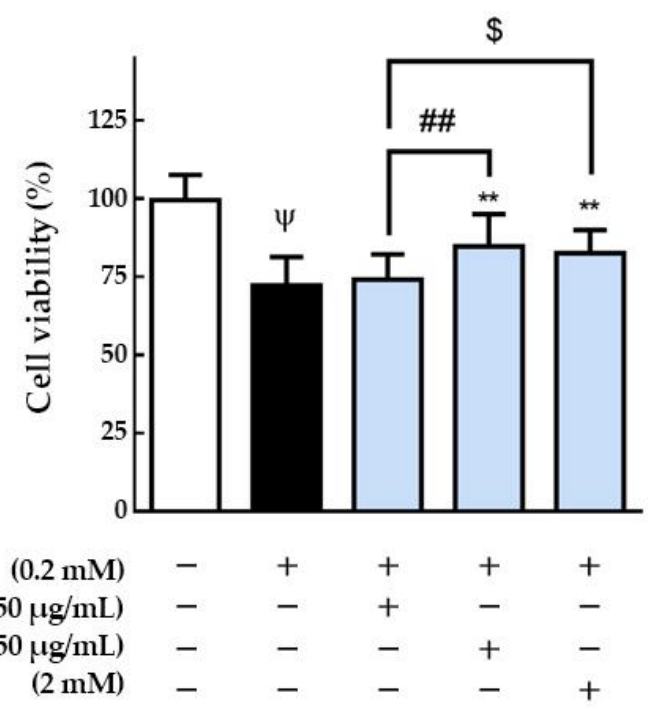

Figure 5. Effect of PPI and PPIH on the cell viability of C2C12 cells. C2C12 myoblasts were cultured (1 $\times 10^{4}$ cells) in $2 \%$ horse serum DMEM to differentiate for 6 days. After 6 days of differentiation, cells were pretreated with $50 \mu \mathrm{g} / \mathrm{mL}$ PPIH for $24 \mathrm{~h}$ and then treated with $0.2 \mathrm{mM} \mathrm{H}_{2} \mathrm{O}_{2}$ for $1 \mathrm{~h} .{ }^{\Psi} p<0.05$ versus control (white column), ${ }^{\#} p<0.01$ compared with PPI and PPIH, ${ }^{\$} p<0.05$ compared with PPI and GSH, ${ }^{* *} p<0.01$ compared with the induced group (black column). PPIH: potato protein isolate hydrolysate. GSH: glutathione. 
Moreover, GSH (2 mM) showed a protective effect against $\mathrm{H}_{2} \mathrm{O}_{2}$-induced oxidative injury $(p<0.01)$. The antioxidant GSH was used as a positive control in this study. GSH serves as a substrate for glutathione peroxidase to eliminate $\mathrm{H}_{2} \mathrm{O}_{2}$, and it exerts its antioxidant action by donating a hydrogen atom to a variety of radicals [36]. However, we also noticed that PPI (50 $\mathrm{gg} / \mathrm{mL})$ did not show a protective effect. Zhang et al. [37] reported that whey protein hydrolysates $(200 \mu \mathrm{g} / \mathrm{mL})$ reduced $\mathrm{H}_{2} \mathrm{O}_{2}$-induced apoptosis by $14 \%$ in a rat pheochromocytoma line 12 . Our results suggested that PPIH showed a protective effect against $\mathrm{H}_{2} \mathrm{O}_{2}$-induced oxidative injury in skeletal muscle cells. Several studies in recent years have shown that protein hydrolysates from the enzymatic hydrolysis of plant proteins can act as a direct scavenger of various free radicals or as an antioxidant [38]. These results also indicated that PPIH could potentially be used as an antioxidant in medical applications. In addition, as shown in Figure 6A, the staining images showed that $\mathrm{H}_{2} \mathrm{O}_{2}$ induced cell morphology changes in $\mathrm{C} 2 \mathrm{C} 12$ cells, and it can be found through image quantification that $\mathrm{H}_{2} \mathrm{O}_{2}$ reduced the number of C2C12 cells. Pretreatment with PPIH $(50 \mu \mathrm{g} / \mathrm{mL})$ had a protective effect $(p<0.001)$. GSH $(2 \mathrm{mM})$ could also significantly restore the oxidative damage caused by $\mathrm{H}_{2} \mathrm{O}_{2}$ (Figure $6 \mathrm{~B}$ ). PPIH is a mixture of free-radical-scavenging amino acids and peptides from plants. It contains several amino acids (essential and nonessential), including branched-chain amino acids (BCAA; valine, leucine, and isoleucine) [39]. It also contains peptides (MW < $500 \mathrm{Da}$ ) presenting antioxidant activity, which were shown to protect C2C12 cells from $\mathrm{H}_{2} \mathrm{O}_{2}$ oxidation. Thus, PPIH could potentially be used as an antioxidant in medical applications and source of amino acid in vegetarian diets and elderly-friendly foods.

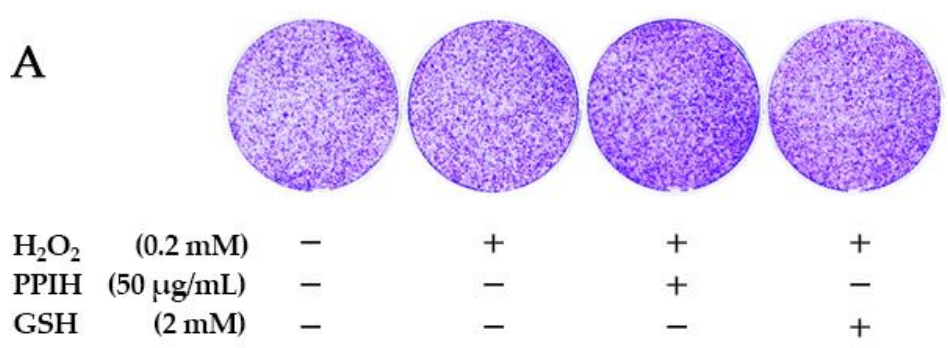

B

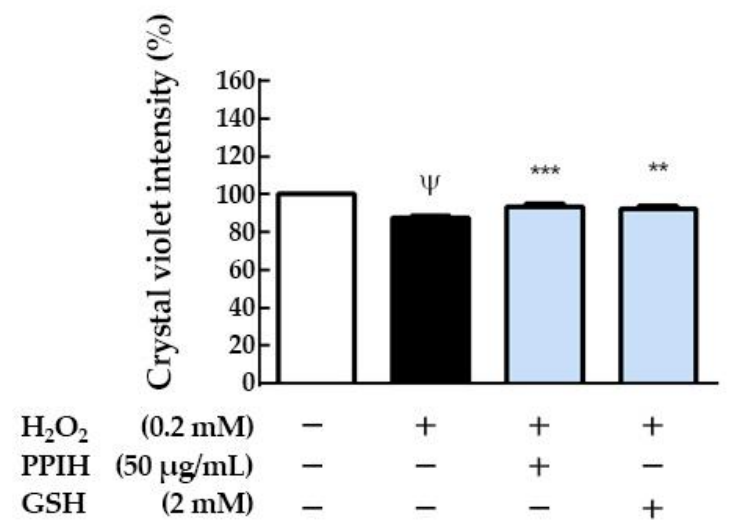

Figure 6. Effect of PPI and PPIH on the cell morphology of C2C12 cells. (A) Cell morphology. (B) Crystal violet intensity. C2C12 myoblasts were cultured $\left(1 \times 10^{4}\right.$ cells) in $2 \%$ horse serum DMEM to differentiate for 6 days. After 6 days of differentiation, cells were pretreated with $50 \mu \mathrm{g} / \mathrm{mL}$ PPIH for $24 \mathrm{~h}$ and then treated with $0.2 \mathrm{mM} \mathrm{H}_{2} \mathrm{O}_{2}$ for $1 \mathrm{~h} .{ }^{\Psi} p<0.05$ versus control (white column), ${ }^{* *} p<0.01$ or *** $p<0.001$ compared with induced group (black column). PPIH: potato protein isolate hydrolysate. GSH: glutathione. 


\section{Materials and Methods}

\subsection{Preparation of PPI and PPIH}

PPI was purchased from Roquette (Lestrem, France). PPIH was prepared by hydrolyzing PPI with the proteases bromelain (Chappion Biotechnology, Chiayi, Taiwan), Neutrase (Novozymes, Bagsvaerd, Denmark), and Flavourzyme (Novozymes, Bagsvaerd, Denmark). Briefly, PPI solution (100 mg PPI/mL) was prepared by dissolving PPI $(1 \mathrm{~kg})$ in distilled water $(10 \mathrm{~L})$ at $95^{\circ} \mathrm{C}$ for a period of $1 \mathrm{~h}$. The proteases bromelain (1000 CDU/mL), Neutrase (0.0024 AU-N/mL), and Flavourzyme (3.3 LAPU/mL) were then added to the PPI solution. The protease-containing PPI solution was incubated at $45{ }^{\circ} \mathrm{C}$ for $24 \mathrm{~h}$. The hydrolyzed PPI solution was heated to $95^{\circ} \mathrm{C}$ and maintained at that temperature for $1 \mathrm{~h}$ to halt protease activity. The PPI solution was then centrifuged at $9000 \times g$ at $4{ }^{\circ} \mathrm{C}$ for $10 \mathrm{~min}$. Filtering the supernatant using No. 1 ADVANTEC filters resulted in a clear, yellow permeate (PPIH solution, $36 \mathrm{mg}$ PPIH/mL). Note that the proteases (bromelain, Neutrase ${ }^{\circledR}$, and Flavourzyme ${ }^{\circledR}$ ) were denatured during the heating and filtration process and were, therefore, not included in the PPIH. Finally, the PPIH solution was freeze-dried and held in an airtight container at $25^{\circ} \mathrm{C}$ prior to use.

\subsection{Solubility of PPI and PPIH under Acidic Conditions}

PPI and PPIH samples (100 mg) were resuspended in $10 \mathrm{~mL}$ of citrate-phosphate buffer (0.1 M, pH 3-6). The samples were stirred at $25^{\circ} \mathrm{C}$ for $10 \mathrm{~min}$ and then centrifuged at $12,000 \times g$ for $20 \mathrm{~min}$ at $25^{\circ} \mathrm{C}$. The protein content of PPI in the precipitate and protein content of PPIH in the supernatant were determined by the Kjeldahl method according to Shen and Kuo [40]. The protein solubility was estimated as the percentage ratio of the protein content of the supernatant to the total original sample's protein content. The protein solubility determinations of all samples were conducted in triplicate. The solubilities of PPI and PPIH were calculated as follows:

$$
\begin{gathered}
\text { PPI solubility }(\%)=100-\left(\frac{\text { protein content of precipitate }}{100 \mathrm{mg}}\right) \times 100 \\
\text { PPIH solubility }(\%)=\frac{\text { protein content of supernatant }}{100 \mathrm{mg}} \times 100
\end{gathered}
$$

\subsection{Determination of the MW Distributions of PPI and PPIH}

The MW distributions of PPI and PPIH were determined by sodium dodecyl sulfate polyacrylamide gel electrophoresis (SDS-PAGE) according to Laemmli [41]. SDS-PAGE analysis of PPI and PPIH was performed with a $12.5 \%$ separation gel and 5\% stacking gel. PPI (6 mg) and PPIH (6 mg) were separately mixed with $1 \mathrm{~mL}$ of buffer $(0.02 \%$ bromophenol blue, $\%$ SDS, $10 \%$ glycerol, $5 \%$-mercaptoethanol, and $70 \mathrm{mM}$ Tris- $\mathrm{HCl}, \mathrm{pH}$ 6.8). Next, the samples were heated at $95^{\circ} \mathrm{C}$ for $7 \mathrm{~min}$. Samples $(10 \mu \mathrm{L})$ and protein ladders $(6 \mu \mathrm{L})$ were loaded into separate wells. After electrophoresis, the gels were stained with Coomassie Brilliant Blue R-250. After staining, the gel was washed with 10\% acetic acid to destain. The stained gel was digitized using an image scanner (Epson America Inc., Long Beach, CA, USA). PPIH was also analyzed by an Autoflex III mass spectrometer (Bruker Daltonik, Bremen, Germany). The masses in the range of 0-500 were measured. Each sample was analyzed in triplicate.

\subsection{The Particle Size of PPI and PPIH}

Particle size distributions (PSDs) of PPI and PPIH were obtained on the basis of the method of Win and Feng [42] using a 90Plus Nanoparticle Size Analyzer (Brookhaven Instruments, Holtsville, New York, NY, USA). PPI and PPIH solutions $(0.05 \% w / v)$ were prepared using the required number of samples solubilized in dd water and stirred for $20 \mathrm{~min}$ at $25^{\circ} \mathrm{C}$. The PPI and PPIH solutions were centrifuged at $12,000 \times g$ for $20 \mathrm{~min}$ at $25^{\circ} \mathrm{C}$. The supernatants of the PPI and PPIH solutions $(3 \mathrm{~mL})$ were loaded into a cuvette to measure particle size. By using the principles of dynamic light scattering, 
the PSD was obtained from the velocity distribution of particles suspended in a dispersing medium. The signal was analyzed with sizes ranging from $1 \mathrm{~nm}$ to $10 \mu \mathrm{m}$. Each sample was analyzed in triplicate.

\subsection{Microstructure of PPI and PPIH}

The microstructures of PPI and PPIH were determined by transmission electron microscopy (TEM) according to Wang et al. [43]. The TEM images of PPI and PPIH were determined using a JEM-1400 instrument (JEOL Co. Ltd., Tokyo, Japan) operated at $100 \mathrm{keV}$. A 300-mesh formvar carbon-coated copper grid was used as the support substrate. The sample was prepared by dropping $10 \mu \mathrm{L}$ of PPI and PPIH solutions onto the grids and blotting the excess sample after $3 \mathrm{~min}$. Positive staining was obtained by adding uranyl acetate to the sample solutions on the TEM grids. Excess uranyl acetate was blotted and then allowed to air-dry. By using Lispixl (NIST freeware), the statistics describing the size distribution of the observed colloids were analyzed. Each sample was analyzed in triplicate.

\subsection{Zeta Potential Measurements}

The zeta potential measurements of PPI and PPIH as a function of $\mathrm{pH}$ were performed on the basis of the method of Tang and Sun [44] using a Zetasizer Nano ZS (Malvern Instruments, Malvern, Worcestershire, UK). Samples were prepared at 1\% under acidic conditions (pH 3-6) adjusted with $\mathrm{HCl} / \mathrm{NaOH}$ solutions. The samples were stirred at $20^{\circ} \mathrm{C}$ before analysis and then centrifuged at $10,000 \times$ $g$ for $10 \mathrm{~min}$. The samples were then measured in triplicate at $20{ }^{\circ} \mathrm{C}$. By using the Henry equation and the Smoluchowski approximation, the zeta potential was calculated from the electrophoretic mobility. Each sample was analyzed in triplicate.

\subsection{ABTS Radical-Scavenging Assay}

The ABTS radical-scavenging assay was determined on the basis of the method of Re et al. [45]. The ABTS solution was prepared by reaction of $5 \mathrm{~mL}$ of a $7 \mathrm{mM}$ ABTS solution and $89 \mu \mathrm{L}$ of a $140 \mathrm{mM}$ potassium persulfate solution. The working solution was further diluted in water until the initial absorbance value of 0.7 at $734 \mathrm{~nm}$. The PPIH sample $(160 \mu \mathrm{L})$ was mixed with $40 \mu \mathrm{L}$ of ABTS solution and mixed with ABTS solution in a 96-well microplate at $30^{\circ} \mathrm{C}$ for $5 \mathrm{~min}$. The absorbance was measured by a microplate reader (Molecular Devices Corporation, Sunnyvale, CA, USA) at $734 \mathrm{~nm}$. The half-maximal effective concentration $\left(\mathrm{EC}_{50}\right)$ of the ABTS free-radical-scavenging activity was calculated from the linear regression curve of percentage inhibition against concentration and further used to determine the antioxidant activity. All determinations were performed in triplicate. The absorbance values were corrected for radical decay using blank solutions.

$$
\text { ABTS radical scavenging activity }(\%)=\left(1-\frac{\text { Abs734 of sample }}{\text { Abs734 of control }}\right) \times 100
$$

\subsection{Cell Culture}

The C2C12 murine myoblast cell line (BCRC 60083), obtained from the Culture Collection and Research Center (CCRC) at the Food Industry Research and Development Institute (Hsinchu, Taiwan), was cultured in Dulbecco's modified Eagle's medium (DMEM, Gibco, Thermo Fisher Scientific, Inc., Waltham, MA, USA) with $10 \%$ fetal bovine serum at $37{ }^{\circ} \mathrm{C}$ with $5 \% \mathrm{CO}_{2}$. To induce differentiation, $70-80 \%$ confluent cells were cultured in a differentiating medium consisting of DMEM supplemented with $2 \%$ horse serum, which was refreshed every two days. After 6 days of differentiation, multinuclear myotubes were formed.

\subsection{Cell Viability Assay}

To evaluate the protective effects of PPI and PPIH on $\mathrm{H}_{2} \mathrm{O}_{2}$-induced oxidative injury in skeletal muscle cells, cell viability was determined using a colorimetric 3-(4,5-dimethylthiazol-2-yl)-2,5diphenyltetrazolium bromide (MTT) assay according to the method of Bahuguna et al. [46]. C2C12 cells 
were seeded in 96-well plates at a density of $0.5-1.0 \times 10^{4}$ cells/well and pretreated with various concentrations of PPI ( $50 \mu \mathrm{g} / \mathrm{mL})$, PPIH ( $50 \mu \mathrm{g} / \mathrm{mL})$, and GSH $(2 \mathrm{mM})$ in serum-free medium for $24 \mathrm{~h}$. Cells were further treated with $0.2 \mathrm{mM} \mathrm{H}_{2} \mathrm{O}_{2}$ for $1 \mathrm{~h}$, after which cell viability was determined by MTT assay. Subsequently, the MTT solution $(1 \mathrm{mg} / \mathrm{mL})$ was added directly to each well (100 $\mu \mathrm{L} /$ well $)$ for $2 \mathrm{~h}$. The cells were then dissolved in DMSO $(100 \mu \mathrm{L} /$ well). The absorbance was measured on an Epoch Microplate Spectrophotometer (BioTek, VT, USA) at $570 \mathrm{~nm}$, with a reference wavelength at $630 \mathrm{~nm}$. $\mathrm{C} 2 \mathrm{C} 12$ cells were also seeded in six-well plates at a density of $1 \times 10^{5}$ cells/well and then stained with crystal violet dye. The color intensity quantification was evaluated by ImageJ software (version 1.52, National Institute of Health, Bethesda, MD, USA). Each sample was analyzed in triplicate.

\subsection{Statistical Analysis}

Data are expressed as the mean \pm standard deviation (SD). Student's $t$-test was used for comparisons between two groups. The statistically significant differences between treatments were determined by one-way ANOVA, and the significance level was set at $p<0.05$. All analyses were performed using GraphPad Prism software version 6.0 for Windows (GraphPad Software, San Diego, CA, USA).

\section{Conclusions}

Our results identified patatin, protease inhibitors, and oxidative enzymes as major proteins in PPI. These proteins were hydrolyzed to PPIH by bromelain, neutral enzymes, and flavor enzymes, resulting in small peptides with improved physicochemical and antioxidative properties. The MW of PPIH $(<500 \mathrm{Da})$ was lower than that of PPI, the particle size was smaller $(<50 \mathrm{~nm})$, and solubility was higher $(>72 \%)$. These properties make PPIH an ideal additive for a wide range of foods, such as drinks and jellies. PPIH also demonstrated ABTS radical-scavenging activity capable of protecting $\mathrm{C} 2 \mathrm{C} 12$ cells from $\mathrm{H}_{2} \mathrm{O}_{2}$ oxidation. Overall, our results indicate that PPIH could be used as an antioxidant in medical applications.

Author Contributions: Formal analysis, data curation, preparation of the research work, writing, and data analysis, C.-Y.C., K.-C.H., and Y.-F.C.; sample preparation, J.-D.J. and H.-L.C.; investigation of the study and review and editing, S.-M.H. All authors have read and agreed to the published version of the manuscript.

Funding: This research was funded from the Ministry of Science and Technology (MOST; Taiwan, Republic of China): the grants number (MOST109-2628-B-038-015-, 109-2314-B-038-059- and 106-2320-B-038-064-MY3).

Conflicts of Interest: The authors declare no conflict of interest.

\section{References}

1. Chung, I.M.; Kim, J.K.; Jin, Y.I.; Oh, Y.T.; Prabakaran, M.; Youn, K.J.; Kim, S.H. Discriminative study of a potato (Solanum tuberosum L.) cultivation region by measuring the stable isotope ratios of bio-elements. Food Chem. 2016, 212, 48-57. [CrossRef] [PubMed]

2. Waglay, A.; Karboune, S.; Alli, I. Potato protein isolates: Recovery and characterization of their properties. Food Chem. 2014, 142, 373-382. [CrossRef] [PubMed]

3. Camire, M.E.; Kubow, S.; Donnelly, D.J. Potatoes and human health. Crit. Rev. Food Sci. Nutr. 2009, 49, 823-840. [CrossRef] [PubMed]

4. Miedzianka, J.; Pęksa, A.; Aniołowska, M. Properties of acetylated potato protein preparations. Food Chem. 2012, 133, 1283-1291. [CrossRef]

5. Fu, Y.; Liu, W.N.; Soladoye, O.P. Towards potato protein utilisation: Insights into separation, functionality and bioactivity of patatin. Int. J. Food Sci. Technol. 2020, 55, 2314-2322. [CrossRef]

6. Elias, R.J.; Kellerby, S.S.; Decker, E.A. Antioxidant activity of proteins and peptides. Crit. Rev. Food Sci. Nutr. 2008, 48, 430-441. [CrossRef]

7. Pihlanto, A.; Akkanen, S.; Korhonen, H.J. ACE-inhibitory and antioxidant properties of potato (Solanum tuberosum). Food Chem. 2008, 109, 104-112. [CrossRef]

8. Gambuti, A.; Rinaldi, A.; Moio, L. Use of patatin, a protein extracted from potato, as alternative to animal proteins in fining of red wine. Eur. Food Res. Technol. 2012, 235, 753-765. [CrossRef] 
9. Spelbrink, R.E.; Lensing, H.; Egmond, M.R.; Giuseppin, M.L. Potato patatin generates short-chain fatty acids from milk fat that contribute to flavour development in cheese ripening. Appl. Biochem. Biotechnol. 2015, 176, 231-243. [CrossRef]

10. Udenigwe, C.C.; Udechukwu, M.C.; Yiridoe, C.; Gibson, A.; Gong, M. Antioxidant mechanism of potato protein hydrolysates against in vitro oxidation of reduced glutathione. J. Funct. Foods 2016, 20, 195-203. [CrossRef]

11. Akbari, N.; Mohammadzadeh Milani, J.; Biparva, P. Functional and conformational properties of proteolytic enzyme-modified potato protein isolate. J. Sci. Food Agric. 2020, 100, 1320-1327. [CrossRef] [PubMed]

12. Asokan, S.M.; Wang, T.; Wang, M.F.; Lin, W.T. A novel dipeptide from potato protein hydrolysate augments the effects of exercise training against high-fat diet-induced damages in senescence-accelerated mouse-prone 8 by boosting pAMPK/SIRT1/PGC-1 $\alpha /$ pFOXO3 pathway. Aging (Albany NY) 2020, 12, 7334-7349. [CrossRef] [PubMed]

13. Evangelho, J.A.D.; Vanier, N.L.; Pinto, V.Z.; Berrios, J.J.; Dias, A.R.G.; Zavareze, E.D.R. Black bean (Phaseolus vulgaris L.) protein hydrolysates: Physicochemical and functional properties. Food Chem. 2017, 214, 460-467. [CrossRef] [PubMed]

14. Kudo, K.; Onodera, S.; Takeda, Y.; Benkeblia, N.; Shiomi, N. Antioxidative activities of some peptides isolated from hydrolyzed potato protein extract. J. Funct. Foods 2009, 1, 170-176. [CrossRef]

15. Moure, A.; Sineiro, J.; Domínguez, H.; Parajó, J.C. Functionality of oilseed protein products: A review. Food Res. Int. 2006, 39, 945-963. [CrossRef]

16. Corrochano, A.R.; Sariçay, Y.; Arranz, E.; Kelly, P.M.; Buckin, V.; Giblin, L. Comparison of antioxidant activities of bovine whey proteins before and after simulated gastrointestinal digestion. J. Dairy Sci. 2019, 102, 54-67. [CrossRef] [PubMed]

17. López-García, B.; Hernández, M.; Segundo, B.S. Bromelain, a cysteine protease from pineapple (Ananas comosus) stem, is an inhibitor of fungal plant pathogens. Lett. Appl. Microbiol. 2012, 55, 62-67. [CrossRef]

18. Merz, M.; Eisele, T.; Berends, P.; Appel, D.; Rabe, S.; Blank, I.; Stressler, T.; Fischer, L. Flavourzyme, an enzyme preparation with industrial relevance: Automated nine-step purification and partial characterization of eight enzymes. J. Agric. Food Chem. 2015, 63, 5682-5693. [CrossRef]

19. Hou, Y.; Wu, Z.; Dai, Z.; Wang, G.; Wu, G. Protein hydrolysates in animal nutrition: Industrial production, bioactive peptides, and functional significance. J. Anim. Sci. Biotechnol. 2017, 8, 24. [CrossRef]

20. Pęksa, A.; Miedzianka, J. Amino acid composition of enzymatically hydrolysed potato protein preparations. Czech J. Food Sci. 2014, 32, 265-272. [CrossRef]

21. Cheng, Y.; Xiong, Y.L.; Chen, J. Antioxidant and emulsifying properties of potato protein hydrolysate in soybean oil-in-water emulsions. Food Chem. 2010, 120, 101-108. [CrossRef]

22. Schmidt, J.M.; Damgaard, H.; Greve-Poulsen, M.; Larsen, L.B.; Hammershøj, M. Foam and emulsion properties of potato protein isolate and purified fractions. Food Hydrocoll. 2018, 74, 367-378. [CrossRef]

23. Chuacharoen, T.; Sabliov, C.M. Stability and controlled release of lutein loaded in zein nanoparticles with and without lecithin and pluronic F127 surfactants. Colloids Surf. A Physicochem. Eng. Asp. 2016, 503, 11-18. [CrossRef]

24. Mahobia, S.; Bajpai, J.; Bajpai, A.K. An in-vitro investigation of swelling controlled delivery of insulin from egg albumin nanocarriers. Iran. J. Pharm. Res. 2016, 15, 695-711. [PubMed]

25. Klompong, V.; Benjakul, S.; Kantachote, D.; Shahidi, F. Antioxidative activity and functional properties of protein hydrolysate of yellow stripe trevally (Selaroides leptolepis) as influenced by the degree of hydrolysis and enzyme type. Food Chem. 2007, 102, 1317-1327. [CrossRef]

26. Midelfort, K.S.; Wittrup, K.D. Context-dependent mutations predominate in an engineered high-affinity single chain antibody fragment. Protein Sci. 2006, 15, 324-334. [CrossRef]

27. Ripple, D.C.; Dimitrova, M.N. Protein particles: What we know and what we do not know. J. Pharm. Sci. 2012, 101, 3568-3579. [CrossRef]

28. Ryan, K.N.; Vardhanabhti, B.; Jaramillo, D.P.; van Zanten, J.H.; Coupland, J.N.; Foegeding, E.A. Stability and mechanism of whey protein soluble aggregates thermally treated with salts. Food Hydrocoll. 2012, 27, 411-420. [CrossRef] 
29. Pouvreau, L.; Gruppen, H.; Piersma, S.R.; van den Broek, L.A.; van Koningsveld, G.A.; Voragen, A.G.J. Relative abundance and inhibitory distribution of protease inhibitors in potato juice from cv. Elkana. J. Agric. Food Chem. 2001, 49, 2864-2874. [CrossRef] [PubMed]

30. Li, Z.R.; Wang, B.; Chi, C.F.; Gong, Y.; Luo, H.Y.; Ding, G.F. Influence of average molecular weight on antioxidant and functional properties of cartilage collagen hydrolysates from Sphyrna lewini, Dasyatis akjei and Raja porosa. Food Res. Int. 2013, 51, 283-293. [CrossRef]

31. Sánchez, A.; Vázquez, A. Bioactive peptides: A review. Food Qual. Saf. 2017, 1, 29-46. [CrossRef]

32. Cheng, Y.; Xiong, Y.L.; Chen, J. Fractionation, separation, and identification of antioxidative peptides in potato protein hydrolysate that enhance oxidative stability of soybean oil emulsions. J. Food Sci. 2010, 75, 760-765. [CrossRef] [PubMed]

33. De Castro, R.J.S.; Sato, H.H. Comparison and synergistic effects of intact proteins and their hydrolysates on the functional properties and antioxidant activities in a simultaneous process of enzymatic hydrolysis. Food Bioprod. Process. 2014, 92, 80-88. [CrossRef]

34. Hood, D.A.; Uguccioni, G.; Vainshtein, A.; D'souza, D. Mechanisms of exercise-induced mitochondrial biogenesis in skeletal muscle: Implications for health and disease. Compr. Physiol. 2011, 1, 1119-1134.

35. Nishida, H.; Ichikawa, H.; Konishi, T. Shengmai-san enhances antioxidant potential in C2C12 myoblasts through the induction of intracellular glutathione peroxidase. J. Pharmacol. Sci. 2007, 105, 342-352. [CrossRef] [PubMed]

36. Kerasioti, E.; Stagos, D.; Priftis, A.; Aivazidis, S.; Tsatsakis, A.M.; Hayes, A.W.; Kouretas, D. Antioxidant effects of whey protein on muscle C2C12 cells. Food Chem. 2014, 155, 271-278. [CrossRef] [PubMed]

37. Zhang, Q.X.; Ling, Y.F.; Sun, Z.; Zhang, L.; Yu, H.X.; Kamau, S.M.; Lu, R.R. Protective effect of whey protein hydrolysates against hydrogen peroxide-induced oxidative stress on PC12 cells. Biotechnol. Lett. 2012, 34, 2001-2006. [CrossRef] [PubMed]

38. Intiquilla, A.; Jiménez-Aliaga, K.; Zavaleta, A.I.; Arnao, I.; Peña, C.; Chávez-Hidalgo, E.L.; Hernández-Ledesma, B. Erythrina edulis (Pajuro) seed protein: A new source of antioxidant peptides. Nat. Prod. Commun. 2016, 11, 781-786. [CrossRef] [PubMed]

39. Gorissen, S.H.M.; Crombag, J.J.R.; Senden, J.M.G.; Waterval, W.A.H.; Bierau, J.; Verdijk, L.B.; van Loon, L.J.C. Protein content and amino acid composition of commercially available plant-based protein isolates. Amino Acids. 2018, 50, 1685-1695. [CrossRef]

40. Shen, Y.R.; Kuo, M.I. Effects of different carrageenan types on the rheological and water holding properties of tofu. LWT-Food Sci. Technol. 2017, 78, 122-128. [CrossRef]

41. Laemmli, U.K. Cleavage of structural proteins during the assembly of the head of bacteriophage T4. Nature 1970, 227, 680-685. [CrossRef] [PubMed]

42. Win, K.Y.; Feng, S.S. Effects of particle size and surface coating on cellular uptake of polymeric nanoparticles for oral delivery of anticancer drugs. Biomaterials 2005, 26, 2713-2722. [CrossRef] [PubMed]

43. Wang, L.S.; Wu, L.C.; Lu, S.Y.; Chang, L.L.; Teng, I.T.; Yang, C.M.; Ho, J.A. Biofunctionalized phospholipid-capped mesoporous silica nanoshuttles for targeted drug delivery: Improved water suspensibility and decreased nonspecific protein binding. ACS Nano 2010, 4, 4371-4379. [CrossRef]

44. Tang, C.H.; Sun, X. Physicochemical and structural properties of $8 \mathrm{~S}$ and/or 11S globulins from mungbean [Vigna radiata (L.) Wilczek] with various polypeptide constituents. J. Agric. Food Chem. 2010, 58, 6395-6402. [CrossRef] [PubMed]

45. Re, R.; Pellegrini, N.; Proteggente, A.; Pannala, A.; Yang, M.; Rice-Evans, C. Antioxidant activity applying an improved ABTS radical cation decolorization assay. Free Radic. Biol. Med. 1999, 26, 1231-1237. [CrossRef]

46. Bahuguna, A.; Khan, I.; Bajpai, V.K.; Kang, S.C. MTT assay to evaluate the cytotoxic potential of a drug. Bangladesh J. Pharmacol. 2017, 12, 115-118. [CrossRef]

Sample Availability: Samples of the compounds are not available. 